NOTICE: this is the author's version of a work that was accepted for publication in the journal, Industrial Marketing Management. Changes resulting from the publishing process, such as peer review, editing, corrections, structural formatting, and other quality control mechanisms may not be reflected in this document. Changes may have been made to this work since it was submitted for publication. A definitive version will be published in Industrial Marketing Management, Volume 43, Issue 4. [InPress] 


\title{
Re-assessing value (co)-creation and cooperative advantage in international networks
}

\author{
Bella Butler and Peter J Batt \\ School of Management \\ Curtin University \\ Perth \\ Western Australia
}

\begin{abstract}
From the Fifth Meeting of the IMP Group in Asia, the ten papers selected for this special edition have been grouped under four broad themes: network evolution and performance; networks in emerging contexts; value (co)creation; and network structure, position and performance. Not unexpectedly, many of the themes overlap, reflecting both the complexity and diversity of network theory.
\end{abstract}

Keywords: cooperative advantage, firms' performance, network evolution, value in networks

\section{Introduction}

From the Fifth Meeting of the Industrial Marketing and Purchasing (IMP) Group in Asia, the following ten papers were selected for this special edition. The papers are broadly grouped under one of four themes: network evolution and performance; networks in emerging contexts; value (co)creation; and network structure, position and performance. Although there are overlaps among and across these topic areas, and each paper generally addresses more than one specific theme, we believe that the selected papers make a relevant contribution to IMP research and contemporary issues in international business studies.

The development and management of business networks remains a popular theme in many streams of business research including strategic management, international business and entrepreneurship. In the strategic management literature, there is a common understanding that the networks of newly created firms evolve as they adapt to the firm's changing resource needs and resource challenges (Hite \& Hesterley, 2001). Inter-firm networks are widely recognized as influencing the internationalization process (Vahle \& Johansson, 2009).

Over the last three decades, the IMP Group has transformed our understanding of inter-firm networks and their role in international operations (Welsh \& Wilkinson, 2004; Gemünden, Ritter \& Walter, 1997; Håkansson \& Snehota, 2000; Johanson \& Mattsson, 1994). Significant changes in the business landscape include the rise of the transitional economies and multinationals, blurring the boundaries between various actors in the distribution and outsourcing networks, and the on-going evolution and transformation of network activities. Changes in the business environment and fierce competition call for different forms of business activities and a reconsideration of prevailing business models in an attempt to generate superior value.

\section{Network evolution and performance}

Within a dynamic market environment, increased uncertainty and fierce competition has 
changed the traditional sources of competitive advantage. Partnerships, collaboration, cooperation and networks now play a crucial role in influencing a firm's ability to access resources, innovations and markets. These same variables also provide a source of sustainable competitive advantage for the firm (Gadde, Huemer \& Hakansson, 2003). Market survival and the performance of firms is no longer possible in isolation: rather, it requires firms to be flexible and cooperative (Håkansson \& Ford, 2002), for the performance of an individual firm now depends upon the performance of others and the quality of the firm's relationships with its business partners (Wilkinson \& Young, 2002).

Examining the network of relationships in which a firm is embedded leads to a greater understanding of the drivers contributing to a firm's performance (Batt \& Purchase, 2004; Gulati, Nohria \& Zaheer, 2000). "A single firm's development cannot be properly understood without including its business relationships and counterparts in the network of which it is a part" (Aaboen, Dubois \& Lind, 2013: p.1034). There is a common view among scholars that firms engage in deliberate strategizing in networks to develop high performing portfolios of relationships to further advance their business (Gulati, 1999; Harrison, Holmen \& Pederson, 2010; Gadde et al., 2003). At the same time, network activities also reflect on a firm's strategy and its engagement with different actors and resources.

This special issue begins with two conceptual articles which both investigate the evolution of networks: the first looks at the historic evolution of distribution networks and the second at the evolution of the selling process. Gadde (this issue) focusses on the evolution of distribution with particular attention towards two specific intermediaries: wholesalers and industrial distributors. Gadde identifies three phases in the historical development of distribution networks which reflect changing market conditions and, accordingly, changes in the position of intermediaries in distribution networks: (1) intermediaries are the dominant actors in distribution; (2) manufacturers challenge the position of intermediaries; and (3) intermediaries regain lost territory. "Over time, intermediaries have been able to maintain, defend, and even improve their positions in distribution networks" through adaptations and the modification of activities, which can be summarised by three main dimensions: "from scale to scope, from speculation to postponement, and from push to pull". Moreover, surviving intermediaries have managed to generate superior value for their business partners, both manufacturers and customers, through a reorientation of their operations to accommodate the prevailing conditions.

Gadde shows how the dynamics of distribution have evolved through the interplay among the three layers of the distribution network: activity, resources and actors. The notion of actors in distribution networks has changed over the years making it more difficult to distinguish between a producer and an intermediary. If at the activity layer value-generating effort is focused on developing the physical infrastructure, and at the resource layer in supporting innovation and business renewal, at the actor layer, value generation requires advanced capabilities and competencies and a reconsideration of business models.

Borg and Young (this issue) introduce the idea of "multi-level" selling to better understand the evolution of the selling process. As a starting point, Borg and Young argue that it is the core competency of the firm which will ultimately determine its performance in the network. Like the previous paper, Borg and Young open with an historic review of the evolution of the selling process, which emphasises the shift from a transactional orientation to a relational perspective and the importance of the firms' surrounding network in generating superior value. This is followed by an introduction to the multi-level (monadic, dyadic and network) 
interpersonal relationship selling process, which is rooted in the IMP research tradition (Håkansson \& Shehota, 2000) and relationship management literature (Freytag \& Philipsen, 2010; Ritter, Wilkinson \& Johnson, 2004). The main contribution of this article is the recognition of the need to manage multiple relationships within the firm's surrounding environment to optimise relationship value. Moreover, optimising a firm's relationship value will also strengthen the firm's network position.

\section{Networks in emerging contexts}

While there is a growing body of business and management literature on the emergent economies, these contexts have seldom been considered from either a strategic network perspective (Gulati et al., 2000; Zaheer \& Bell, 2005) or by the IMP Group (Håkansson \& Ford, 2002). Emergent economies are characterized by underdeveloped market-support institutions (Khanna \& Palepu, 2000), rapid change (Drummond, 2012), and rapid growth in the economy through economic liberalization (Hoskisson et al., 2000). To compete in the emerging markets, firms need to reposition themselves in business networks, adjust their network strategy, adjust their relationships with partners, and consider changes to product mobility and geographic configuration (Lorentza et al., 2013). The following papers build on the notion of value co-creation and developing competitive advantage from cooperation among firms in diverse business contexts.

Huemer (this issue) explores how cooperative advantage can be developed from the reorientation of often conflicting interests between multinational corporations (MNCs) and indigenous peoples. Huemer explores the relationships between "one of the world's most wealthy and modern organisational entities", namely Mainstream Canada, a subsidiary of Norwegian aquaculture giant Cermaq, and "one of the most marginalized, poor and traditional groups" - the Ahousaht First Nation, the indigenous people on the west coast of Vancouver Island, where Mainstream has been engaged in salmon farming in Ahousaht territory since 2000 . This case illustrates how through interaction, the relationship between these two very different actors has evolved from competitive to more cooperative activities and a common vision towards salmon farming.

Exploring the notion of cooperative advantage, Huemer compares and contrasts the dimensions of competitive and collaborative advantage. Following Cao and Zhang (2011), Huemer (this issue) defines cooperative advantage as "strategic benefits gained over competitors in the marketplace through supply chain partnering". Huemer notes that managers need to align goals and benefits with supply chain partners to create collaborative advantage, which is advanced through patience, acknowledgement and respect.

Schepis, Purchase and Ellis (this issue) discuss the tensions between traditionally competitive business networks and the managerial challenges associated with Western corporations interacting with indigenous communities. This study is set in the mining industry in Western Australia where firms proactively engage with indigenous owned businesses in response to their perceived corporate social and legal responsibility. The authors provide interesting insights into indigenous businesses and their position within the industrial network, which facilitates their ability to access resources and opportunities.

Indigenous engagement strategies employed by the major mining companies have the potential to alter the structure and processes of a network, thus creating a new network identify. The analysis of network positions and identities presented in this paper shows that to 
overcome some socio-economic and cultural challenges, and to foster the development of indigenous businesses, a "somewhat artificial market" and a "cocooned sub-network to the mainstream mining industry" has emerged. The main contribution of this study is in demonstrating how powerful network actors influence the structure and process of the network, acting to form a sub-network with non-conventional motivations and values. The paper further contributes to our theoretical understanding of network behaviour by illustrating how managers take advantage of available methods to assert their firm's identities and positions within the network.

AlHussan, AlHussan and Fletcher-Chen (this issue) explore the choice between standardization and adaptation of key account management (KAM) practices within an Arab context. They conclude that the intensity of competition and ownership structure, product and customer complexity, Western influence on education and business, and institutional and cultural factors, including the concept of wasta, influence KAM practices and thus the extent to which multinational companies are able to transfer their KAM practices. While some factors align with Western business knowledge and culture, which facilitates standardisation, other institutional characteristics require adaptation to local practices.

Continuing to explore the impact of a diverse institutional context in the emergent economies, Rod, Lindsay and Ellis (this issue) investigate the co-creation of value in relationships between Western (New Zealand) service and service-intensive companies and their exchange partners in China and India, the two fastest-growing emergent markets. Whereas Chinese managers use cooperation with their Western partners "as a means of making transactions more cost-effective, or to fill gaps in their supply chains", Indian managers use partnerships "as a means for co-creating value where they and their New Zealand suppliers are jointly involved in co-creating value within a service system, creating value-in-use".

\section{Value (co)-creation in supplier and seller networks}

The concept of economic value and value creation has recently emerged as the primary consideration in decision-making and management practices (Druker, 1993; Haas, Snehota \& Corsaro, 2012; Levitt, 1983). Ever since the role of relationships in value creation was first recognised (Ford, Gadde, Hakansson \& Snehota, 2003; Grönroos, 1997), business scholars have shown immense interest in exploring and assessing the value of business relationships (Corsaro \& Snehota, 2010; Gadde \& Snehota, 2000; Grönroos, 2008 and 2011; Haas et al., 2012; Möller \& Törrönen, 2003). Research on service logic (Sheth, Sisodia \& Sharma, 2000; Norman, 2001), service-dominant logic (Vargo \& Lusch, 2004) and the following discussion of service as "a perspective of value creation rather than a category of market offerings" (Edvardsson et al., 2005: 118) has opened a new stream of research highlighting the role of customers in creating value for themselves and acknowledging the role of firms in developing opportunities for customers "to co-create value with them and for them" (Grönroos, 2008: p.299). Prahalad and Ramaswamy (2004) highlight the benefits of customers being involved in the co-creation of value, stressing that value is embedded in "individualised" experiences.

The contemporary management and marketing literature (see Jones et al., 2005) acknowledge the role of customers as co-creators of value. It is recognised that suppliers facilitate the creation of value and customers can "engage themselves with the supplier's work and enter it as co-creators" (Grönroos, 2008: p.305). Vargo and Lusch (2004) emphasise the role of the customer as a co-creator of value and the importance of proactive customer involvement in the value co-creating process. In today's dynamic and turbulent market, the role of customers 
is evolving from a passive recipient of transactions to an active contributor to a firm's product, service, or capability (Yang and Liu, 2012).

Baraldi, Proenca, Proenca and Castro (this issue) consider the outsourcing company as a customer and examine how value is created within the framework of strategic outsourcing. In contrast to the majority of research on strategic outsourcing, which traditionally focuses on the outsourcing firm and its decision to "make or buy" and the choice of suppliers or offshoring countries, this study focuses on the "other" perspective of strategic outsourcing, specifically, the supplier.

This in-depth case study of a Portuguese packaging company illustrates the long term relationship that is promoted through common mutual adaptations and informal arrangements between the supplier (Logoplast) and its customers. While relationship specific investments and adaptations increase the dependency between partners and decrease the flexibility of the supplier, this type of relationship and its physical proximity provide distribution and inventory cost savings for both parties.

This study confirms the need to acknowledge the relationships that support strategic outsourcing (Håkanson \& Shehota, 1995). Baraldi, Proenca, Proenca and Castro (this issue) identify key dimensions which can be generalised and applied to the analysis of any outsourcing relationship. The study emphasizes the role of cooperation, reciprocity and mutual dependence as major drivers of outsourcing as well as fundamental ways of creating additional value. Value is co-created together by the outsourcing companies and the supplier as a result of closer dialogues and coordination. However, both the outsourcing company and the supplier "interact within a complex, durable and deep business relationship", in which both parties are mutually dependent because the supplier takes over the customer's activities. This interdependence blurs the organisational boundaries between the outsourcing company and the supplier.

The notion of value is further discussed by Leach and Liu (this issue), who develop a typology to demonstrate how sales firms evaluate defected customers and the likelihood of their reacquisition or winning back. The likelihood of customer reacquisition requires an assessment of the barriers to reacquisition, leveraging any remaining customer relationship, as well as the sales company's own value-adding capabilities. The value of a customer is determined by their account size, profitability, market influence and cross-selling potential.

Leach and Liu (this issue) highlight the difference between winning back a lost customer and acquiring a new one. Indeed, as the authors explain, when customers leave a relationship "they may leave behind a wealth of transaction-specific information, such as transaction history". Strategically influencing the customer relationship may lead to the reacquisition of lost customers which, in turn, facilitates profitable exchange relationships enriching overall customer engagement.

How easy it is to win-back lost customers depends on the following four factors: (1) the ability to influence relations within the customer firm and other firms in the customer's value chain; (2) the ability to develop a competitive win-back offer; (3) the capacity to overcome any significant barriers to reacquisition; and (4) the ability to consolidate organisational resources for the purpose of reacquisition. In parallel, the study found that each of the following factors increased the value of winning back the customer: (1) account size, as large customers have a greater impact on the sales firm's revenue; (2) account profitability; (3) 
market influence, which is determined by the customer's referral potential, leadership, innovativeness and brand image; and (4) cross-selling opportunities, which can be identified as the ability to cross-sell other products or to other divisions within the customer organisation. Understanding the interplay between these two groups of factors (the ease of win-back and the value of win-back) assists firms in viewing customers as co-producers, which ultimately increases the value of the sales firm (Ritter et al., 2004).

While traditionally IMP researchers have studied firms' collaborative efforts in networks, Ford and Håkansson (2013) argue that in any business relationship, firms compete as well as cooperate. Moreover, a firm's decision to join a network and to contribute collective benefits may be driven by their self-interest (Håkansson \& Shehota, 1995). The interplay between self and collective interests in a network provides an important insight into how networks evolve over time (Medlin, 2006).

Munksgaard and Medlin (this issue) examine the extent to which a firm's business is shaped and influenced by network creation initiatives. The context of their study is a policy generated network established to achieve social and economic benefits. Specifically, the paper presents a single case study of a regional network of 26 food producers called "Temptations of South Denmark". This network is a result of a regional government-funded initiative with a formal goal of promoting regional food products and collectively promoting individual members. This study observed how various combinations of firms' self and collective interests determined the extent to which members' engaged in network activities.

Active members engaged in the network possess "the ability to convert collective interests in the network to self-interest". This adds a new dimension to network competence, namely an ability to convert combined activities into self-interest gains for the firm. This competence to convert combined activities into self-interest gains was found to be unrelated to the firms' perception of their own role in the network or to the role of others. The ability of firms to derive business opportunities from formal networks was found to have no connection to the degree of firms' engagement with formal network activities.

Most of the network's 'non-active' members were mostly guided by self-interest. Here Munksgaard and Medlin (this issue) posit that a reason for their inactivity might be "the nonalignment of interests with the outcomes perceived possible from this particular network or their opinion concerning formal networking".

\section{Network structure, network position and performance}

The impact of a firms' network structure and network position on firm performance is well recognised in business research, particularly in strategic management (Burt, 1992, 2000; Gulati et al., 2000; McEvily \& Zaheer, 1999; Zaheer \& Bell, 2005). Burt (1992, 2000) argued that there is a high probability of better performance for firms with a more advantageous network position, which facilitates bridging structural holes - the gaps between otherwise disconnected firms in the network - due to their superior access to information and other resources. Powel et al. (1996), Tsai (2001) and Wong and Fang (2012) demonstrate that organisations in a central position in their network have superior bargaining power as a result of preferential access to information and resources. While interactive strategic measures can be taken to influence the firm's position in the network to a more favourable one (Gadde et al., 2003), Wilkinson and Young (2002) argue that firms do not have the propensity to directly control their position in their respective networks. 
Zaheer and Bell (2005: 823) stressed that "firms with superior network structure are better able to exploit their internal capabilities to enhance their performance". While "network scholars tend to focus attention on the value of network structure, without considering the capabilities of the actors tied together by the network", it is important to fuse these two streams of research and consider "the internal capabilities of the actors in a network together with capabilities they derive from the structure of the network that binds them together". Recently, Yang and Liu (2012) found that firms' superior network position mediates the impact of organisational agility on firm performance.

The final article in this special issue focuses on the role of the Chief Executive Officer (CEO) on the performance of small-to-medium sized enterprises. This paper tests the extent to which the performance of SMEs is driven by internal factors such as the CEO's managerial style, and the extent to which it is driven by external factors, such as the network structure. In this paper, Naude, Zaefarian, Tavani, Neghabi and Zaefarian (this issue) utilise a recently introduced neurostrategy stream of research (Powel, 2011) into their study. In particular, the authors investigate how two mediating factors, namely network structure and entrepreneurial style, mediate the association between SMEs performance and some of its antecedents, namely the CEO's emotional intelligence and networking behaviours. Not only does this study bring together different streams of research, such as network theory, emotional intelligence theory and entrepreneurship theory, but it also employs, for the first time to our knowledge, a dual methodology, namely structural equation modelling and social network analysis.

Naude et al. (this issue) acknowledge that in recent years, SMEs have become a strong competitive force, influencing the economies of many countries around the world by creating new jobs and developing new products, services and processes, and ultimately "helping nations to rebuild their economies after the recession". The data for this study was gathered from SMEs in the information technology sector in Iran, a turbulent market with limited access to resources. In this market, competitive advantage was derived from the ability of top management to strategically position themselves in embedded networks. Emotional intelligence can be considered as an antecedent to "structural holes" and "network centrality". Moreover, emotional intelligence can enhance networking behaviours and entrepreneurial style.

\section{Acknowledgements}

In bringing you this special edition, we wish to acknowledge the many reviewers who have so generously provided their expert judgements: Enrico Baraldi, Susanne W. Borg, Guido Bortoluzzi, Daniel Chicksand, Ann H. Clark, Nick Ellis, Bente M. Flygansvaer, Per Vagn Freytag, Lars-Erik Gadde, Virpi Havila, Stephan Henneberg, Lars Huemer, Marianne Jahre, Mark P. Leach, Sheena Leek, Annie Liu, Chris Medlin, Stefanos Mouzas, Pete Naude, João F. Proença, Sharon Purchase, Jakob Rehme, Thomas Ritter, Michel Rod, Dionysis Skarmeas, Henrikki Tikkanen, Terje I. Vaaland and Ian Wilkinson.

\section{References}

Aaboen, L., Dubois, A. \& Lind, F. (2013). Strategizing as networking for new ventures. Industrial Marketing Management, 42, 1033-1041. 
Batt, P.J. \& Purchase, S. (2004). Managing collaboration within networks and relationships. Industrial Marketing Management, 33, 169 - 174.

Burt, R.S. (1992). Structural Holes: The Social Structure of Competition. Harvard University Press, Cambridge, MA.

Burt, R.S. (2000). The network structure of social capital, in Sutton, R. I. and Staw, B. M. (Eds.), Research in Organisational Behaviour, JAI press, Greenwich, CT, $345-423$.

Cao, M. \& Zhang, Q. (2011). Supply chain collaboration: Impact on collaborative advantage and firm performance. Journal of Operations Management, 29, 163 - 180.

Corsaro, D. \& Snehota, I. (2010). Searching for Relationship Value in Business Markets: Are We Missing Something? Industrial Marketing Management, 39, 986 -995.

Drummond, A. (2012). Research on emergent economies: challenges are always opportunities. Global Strategy Journal, 2: $48-50$.

Edvardsson, B., Gustafsson, A. \& Roos, I. (2005). Service portraits in service research: a critical review, International Journal of Service Industry Management, 16 (1), 107 - 121.

Ford, D., Gadde, L-E., Håkansson, H. \& Snehota, I. (2003). Managing business relationships (2nd ed.). Chichester: John Wiley and Sons.

Ford, D. \& Håkansson, H. (2013). Competition in business networks. Industrial Marketing Management, 42, $1017-1024$.

Freytag, P.V. \& Philipsen, K. (2010). Challenges in Relationship Marketing, Academica, 212 p.

Gadde, L-E. \& Snehota, I. (2000). Making the most of supplier relationships. Industrial Marketing Management, 29(4), 305-316.

Gadde, L-E., Huemer, L. \& Håkansson, H. (2003). Strategizing in industrial networks, Industrial Marketing Management, 32(5), 357-364.

Gemünden, H.G., Ritter, T. \& Walter, A. (1997). Relationships and Networks in International Markets. Pergamon.

Gulati, R. (1999). Network location and learning: The influence of network resources and firm capabilities on alliance formation, Strategic Management Journal, 20(5), 397-420.

Gulati, R., Nohria, N. \& Zaheer, A. (2000). Strategic networks, Strategic Management Journal, 21, 203-215.

Grönroos, C. (1997). Value-driven relational marketing: From products to resources and competences. Journal of Marketing Management, 13(5), 407-420.

Grönroos, C. (2008). Service logic revisited: who creates value? And who co-creates? European Business Review, 20 (4), 298-314. 
Grönroos, C. (2011). A service perspective on business relationships: The value creation, interaction and marketing interface, Industrial Marketing Management, 40, 240 -247.

Haas, A., Snehota, I. \& Corsaro, D. (2012). Creating value in business relationships: The role of sales. Industrial Marketing Management, 41, 94- 105.

Håkansson, H. \& Ford, D. (2002). How should companies interact in business networks? Journal of Business Research 55(2), 133-139.

Håkanson, H. \& Shehota, I. (1995). Developing Relationships in Business Networks, Routledge, London.

Håkansson, H. \& Snehota, I. (2000). The IMP Perspective: Assets and Liabilities of Business relationships in Sheth, J.N., Parvatiyar, A., (eds) Handbook of Relationship Marketing, Thousands Oak: Sage, 69-94.

Harrison, D., Holmen, E. \& Pederson, A-C. (2010). How companies strategize deliberately in networks using strategic initiatives. Industrial Marketing Management, 39, 947 - 955.

Hite, J.M. \& Hesterly, W.S. (2001). The evolution of firm networks, Strategic Management Journal, 22(3), 275-286.

Hoskisson, R.E., Lau, E.L. \& Wright, M. (2000). Strategy in emergent economies. Academy of Management Journal, 43 (3): 249- 267.

Johanson, J. and Vahlne, J-E. (2009), The Uppsala internationalization process model revisited: from liability of foreignness to liability of outsidership, Journal of International Business Studies, 40 (9), 1411-1431.

Johanson, J. \& Mattsson, L-G. (1994). The Markets-as-Networks Tradition in Sweden, in Laurent, G., Lilien, G.L. \& Pras, B. (eds.), Research Traditions in Marketing. Boston: Kluwer Acadmic Publishers, 321-342.

Jones, E., Brown, S.P., Zoltners, A.A. \& Weitz, B.A. (2005). The changing environment of selling and sales management. Journal of Personal Selling and Sales Management, 15 (2), $105-111$.

Khanna, T. \& Palepu, K. 1997. Why focused strategies may be wrong for emergent markets. Harvard Business Review, 75 (4): $41-51$.

Levitt, T. (1983). The marketing imagination, New York, NY: Free Press.

Lorentz, H., Kittipanya-ngam, P. \& Srai, J.S. (2013). Emerging market characteristics and supply network adjustments in internationalising food supply chains, International Journal of Production Economics, 145 (1), 220 - 232.

McEvily, B. \& Zaheer, A. (1999). Bridging ties: A source of firm heterogeneity in competitive capabilities, Strategic Management Journal, 20(12), 1133-1158. 
Medlin, C.J. (2006). Self and collective interest in business relationships, Journal of Business Research, 59 (7), 858-65.

Möller, K.E. \& Törrönen, P. (2003). Business suppliers' value creation potential: A capability-based analysis, Industrial Marketing Management, 32(2), 109-118.

Powel, W.W., Koput, K. \& Smith-Doerr, L. (1996). Interorganizational collaboration and the locus of innovation: Networks of learning in biotechnology, Administrative Science Quarterly, 41, 116-145.

Powel, T.C. (2011). Neurostrategy, Strategic Management Journal, 32 (13), 1484 -1499.

Prahalad, C.K. \& Ramaswamy, V. (2004). The Future of Competition: Co-creating Unique Value with Customers, Harvard Business School Press, Boston, MA.

Ritter, T., Wilkinson, I.F. \& Johnston, W.J. (2004). Firms' Ability to Manage in Business Networks: A Review of Concepts, Industrial Marketing Management, 33, 175-183

Sheth, J.N., Sisodia, R.S. \& Sharma, A. (2000). The antecedents and consequences of customer-centric marketing, Journal Academy of Marketing Science, 28(1): 55-66.

Tsai, W. (2001). Knowledge transfer in intraorganizational networks: effects of network position and absorptive capacity on business-unit innovation and performance. Academy of Management Joornal, 44, 996 - 1004.

Vahle, J-E. \& Johansson, J. (2013). The Uppsala model on evolution of the multinational business enterprise - from internalization to coordination of networks, Multinational Business Enterprise, 30 (3), $189-210$.

Vargo, S.L. \& Lusch, R.F. (2004). Evolving to a new dominant logic for marketing, Journal of Marketing, 68, 1-17.

Welsh, C. \& Wilkinson, I. (2004). The political embeddedness of international business networks, International Marketing Review, 21 (2), 216-231.

Wilkinson, I. \& Young, L. (2002). On cooperating: Firms, relationships and networks, Journal of Business Research, 55 (2), 123 - 132.

Wong, M-C. \& Fang, S.-C. (2012). The moderating effect of environmental uncertainty on the relationship between network structures and the innovative performance of a new venture. Journal of Business \& Industrial Marketing, 27 (4), 311 - 323.

Zaheer, A. \& Bell, G.G. (2005). Benefiting from network position: firm capabilities, structural holes, and performance. Strategic Management Journal, 26 (9), 809-825.

Yang, C. \& Liu, H-M. (2012). Boosting firm performance via enterprise agility and network structure. Management Decision, 50 (6), 1022- 1044. 